\title{
The assess of the ecological functioning of urban ecosystems of Białystok using the methods of monitoring with lichens
}

\author{
Anna Matwiejuk \\ Department of Botany, Institute of Biology, University of Białystok \\ Świerkowa 20B, PL-15-950 Białystok \\ e-mail: matwiej@uwb.edu.pl
}

\begin{abstract}
The paper attempts to assess the ecological functioning of urban ecosystems of Białystok using the bioindication methods - lichen response to gaseous pollutants originating mainly from the transport and combustion of fossil fuels in power plants and household furnaces. To assess the degree of air pollution by sulfur dioxide $\left(\mathrm{SO}_{2}\right)$ in the area of the city of Białystok, three lichen-indicative methods were used: 1 . floristic approach, 2. method of participation of morphological forms, and 3. chemical analytical method involving the analysis of the chemical composition of trace elements $(\mathrm{Pb}, \mathrm{Ni}, \mathrm{Cu}, \mathrm{Zn}, \mathrm{Fe})$ in the thallus of Hypogymnia physodes.
\end{abstract}

Key words: lichens, bioindicators, monitoring with lichens, trace elements, Białystok, Poland NE.

\section{Introduction}

The development of civilization leads to atmospheric penetration by substances which are toxic and dangerous for the whole animate nature. Under natural conditions, devoid of anthropogenic human impact, the air is free of oxides of nitrogen (NOx) and sulfur (SOx), particulates, heavy metals and other pollutants. For the most part, the main sources of gaseous and particulate emissions entering the atmosphere are: industry, road transport and combustion of energy fuels.

Despite the very precise technical methods informing us about certain levels of contamination of the environment, issues of environmental assessment using biomarkers have broadly participated in the control of the natural environment (Zimny 2006; Kłos 2007).

The evaluation of environmental performance is a branch of applied ecology using different reactions of living organisms to environmental factors in order to determine the degree of deformation of the natural environment (Zimny 2006). An indicator organism, as a bioindicator showing some irregularities in the functioning of ecosystems may be a species, ecological form, population, association or community of species in a particular ecological situation (Jachnik 2006). These are usually the species with a narrow range of tolerance (stenobionts) or with a specific way of responding to a given substance.

Within the bioindicators there are two basic groups: appropriate bioindicators (sensitive indicators), which react to environmental changes visually, e.g. with morphological changes or changes in species composition and accumulators (accumulative indicators), which collect various toxic compounds, whose concentration can be determined analytically (Zimny 2006).

A classic example of bioindicators for air pollution are lichens (Lichenes), which as a result of the symbiotic merger of two organisms, namely a fungus (mycobiont) and green alga and/or cyanobacterium (photobiont) created a new kind of organism. The versatility of lichens as bioindicators is due to their very high sensitivity to pollution, particularly sulfur dioxide $\left(\mathrm{SO}_{2}\right)$ and the reproducibility of their response in different areas. 
There are several reasons why lichens have enjoyed such an extraordinary success in this field: 1) lichens are ubiquitous and are currently increasing in many urban areas as a direct consequence of decreased $\mathrm{SO}_{2}$ levels; 2) they lack a protective outer cuticke and absorb both nutrients and pollutants over much of their outer surface from predominantly aerial sources; 3 ) their symbiotic nature; 4) they are perennial organisms available for monitoring throughout the year; 5) many lichen species accumulate high metal contets without exhibiting damage, thereby permitting monitoring over wide areas; 6) different methods exist providing opportunities for all ages and abilities (Nimis \& Purvis 2002).

Lichens have been used worldwide as air pollution monitors because relatively low levels of sulfur, nitrogen, and fluorine-containing pollutants (especially $\mathrm{SO}_{2}$ and $\mathrm{F}$ gas, and acidic or fertilizing compounds), adversely affect many species, altering lichen community composition, growth rates, reproduction, physiology, and morphological appearance. Lichens are also used as pollution monitors because they concentrate a variety of pollutants in their tissues. Reviews of the literature and methods regarding air quality assessment using lichens include Nash and Wirth (1988); Nash (1989); Richardson (1992); Hyvärinen et al. (1993); Garty (2001); Nash and Gries (2002); Nimis et al. (2002).

Through their presence, species composition, morphology of thallus and its size, lichens provide information about the state of the environment (Bystrek 1997; Nimis et al. 2002). The other main advantages of lichens as bioindicators and biomonitors include the following features: they are resistant to many types of pollutants accumulating in their biological structures; homeostasis disorder caused by air pollution makes many measurable anatomical, morphological and physiological changes in lichens; due to their sorptive properties they accumulate in their structure trace elements, often showing their origin (Kłos 2007).

For air monitoring primarily epiphytic lichens that grow on the bark of deciduous and coniferous trees are used (Fałtynowicz 1995).

Conducting air monitoring with the use of lichens, we do not receive information on chemical contamination or the effects of individual compounds. The obtained results are the effect of a complex influence of mixtures of harmful chemicals (Zimny 2006).

Unusual properties of lichens were discovered in the nineteenth century. They first drew attention of biologists to the fact that plants can be indicators of adverse changes in the atmosphere (Nylander 1866). Since the times of Nylander many field and laboratory studies have been carried out on lichens as bio-indicators of air pollution. Studies and monitoring of lichens which resulted in designating areas for varying conditions of vegetation were carried out in many cities in the world (Sernander 1926; Vaarna 1934;
Sauberer 1951 and others). They all analyzed the lichen vegetation zones and plotted their ranges. In the period since the end of World War II, several large Polish cities have also lived to see more research on lichens and marking of lichen-indicative zones (Rydzak 1953; Kozik 1970; Kiszka 1977, 1999; Wilkoń-Michalska et al. 1988; Fałtynowicz et al. 1991).

Hawksworth and Rose (1970) designed a 0-10 zone system, a calibrated scale for the United Kingdom. The Hawksworth and Rose system was adapted to the Polish climate and the southern Polish lichenobiota by Kiszka (1990).

The purpose of this study was to assess the ecological functioning of urban ecosystems of Białystok using the bioindication methods - lichen response to gaseous pollutants originating mainly from the transport and combustion of fossil fuels in power plants and household furnaces. Research has also been undertaken to compare the environmental status of Białystok after ten years, when I first conducted lichen-indicative studies there (Matwiejuk 2007).

\section{Study area}

Białystok lies on the Podlasie Lowland (Nizina Podlaska), the region of Białystok Plateau, on the Biała River - a leftbank tributary of the Supraśl, in the center of Podlaskie region (Kondracki 2002). Białystok is the capital of the Podlaskie Voivodship, inhabited by over 292 thousand people (as on 31 December 2009). Among the Polish provincial cities, it is the second biggest in terms of population density $\left(2,886\right.$ persons $\left./ \mathrm{km}^{2}\right)$, the eleventh in terms of population and thirteenth in terms of area $\left(102.3 \mathrm{~km}^{2}\right)$.

Białystok is the largest industrial centre of the province. The dominant industry is: food (production of beverages and food), electrical engineering (electronics, machinery and metal), wood, construction materials, textiles. Białystok is a city where urban greens comprise around $32 \%$ of its area. Within Białystok, there are two nature reserves (Zwierzyniecki Forest and Antoniuk Forest) with the total area of 105 ha. The metropolitan area is adjacent to the forest complex of the Knyszyńska Forest and Narew National Park.

Currently, the main sources of air pollutant emissions in the city of Białystok are large energy facilities (Białystok Power and Heat Plant Plc, West District Heating and ENERGY-TECH Ltd. in Białystok, Poland) and industrial objects of the municipal and household sector and mobile sources (motor vehicles). Substances having the largest share of emissions, mainly from combustion processes include sulfur dioxide $\left(\mathrm{SO}_{2}\right)$, nitrogen oxides (NOx), carbon monoxide $(\mathrm{CO})$ and dust. Other types of pollutants emitted from industrial plants result from the type of production and technology. Of great importance in the overall balance 
of pollutants from the city is the municipal and household sector, difficult to estimate, the so-called low emission, which includes mainly household furnaces in detatched houses, small boiler rooms, craft-service objects. Low emission has impact on the increase in the concentration of sulfur dioxide, nitrogen dioxide and dust in the heating season, especially during adverse weather conditions. The communication system also significantly impacts the air quality. As a result of fuel combustion in car engines gaseous pollutants leak into the atmosphere: nitrogen oxides, carbon monoxide, carbon dioxide and hydrocarbons (particularly benzene), and dust containing compounds of lead, cadmium, nickel and copper. The condition of air pollution in Białystok is significantly affected by transit traffic arising from the location of border crossings with Belarus and Lithuania, causing increased share of trucks in the total number of vehicles.

Performed annually "Assessment of air substance levels and the classification of zones of the Podlaskie Voivodship in 2009" (Journal of Laws no. 62 of 20 June 2001) did not show exceedances of acceptable air pollution standards for healthcare criteria and plant protection in the agglomeration of Białystok (Bok 2010). According to data of Statistical Yearbook of Podlaskie Voivodship from the year 2009, during the years 2000 to 2004 Białystok saw an increase in emissions of dust and gas and in the next few years there has been a fall.

\section{Materials and methods}

To assess the degree of air pollution by sulfur dioxide $\left(\mathrm{SO}_{2}\right)$ in the area of the city of Białystok, three lichen-indicative methods were used: 1) floristic approach, 2) method of participation of morphological forms, and 3) chemical analytical method involving the analysis of the chemical composition of trace elements in the thallus of Hypogymnia physodes. The study methods were based on methods provided by Fałtynowicz (1995). The concentration of $\mathrm{SO}_{2}$ for each zone according to Fałtynowicz (1995).

Field studies were conducted in 2009-2010 in six city districts, varying in the degree of urbanization. Two measurement points (stands) were set in the center of the city of Białystok, where the city parks are located: the Planty Park (1) and the Prince Józef Poniatowski Old Park (2), integrated into the urban landscape, and characterized by the immediate proximity of transportation routes with a high traffic volume. The next two test points were located on the outskirts of the city within the Solnicki Forest (3), a dense forest complex situated in the south of the city and around the Pietrasze Forest (4), a dense forest complex situated in the north of the city. The last two points were set in the housing estates located in remote parts of the city, one within the Sunny Slope estate (5), the other in Dojlidy estate (6). In each of the sites epiphytic lichen species were identified along with their morphological forms and the amount of exposure and the height on the trunk.

Figure 1 shows localization of stands.

Figure 1. Distribution of stands in Białystok Stands: 1 - Planty Park, 2 - Old Park, 3 - Solnicki Forest, 4 - Pietrasze Forest, 5 - Słoneczny Stok, 6 - Dojlidy

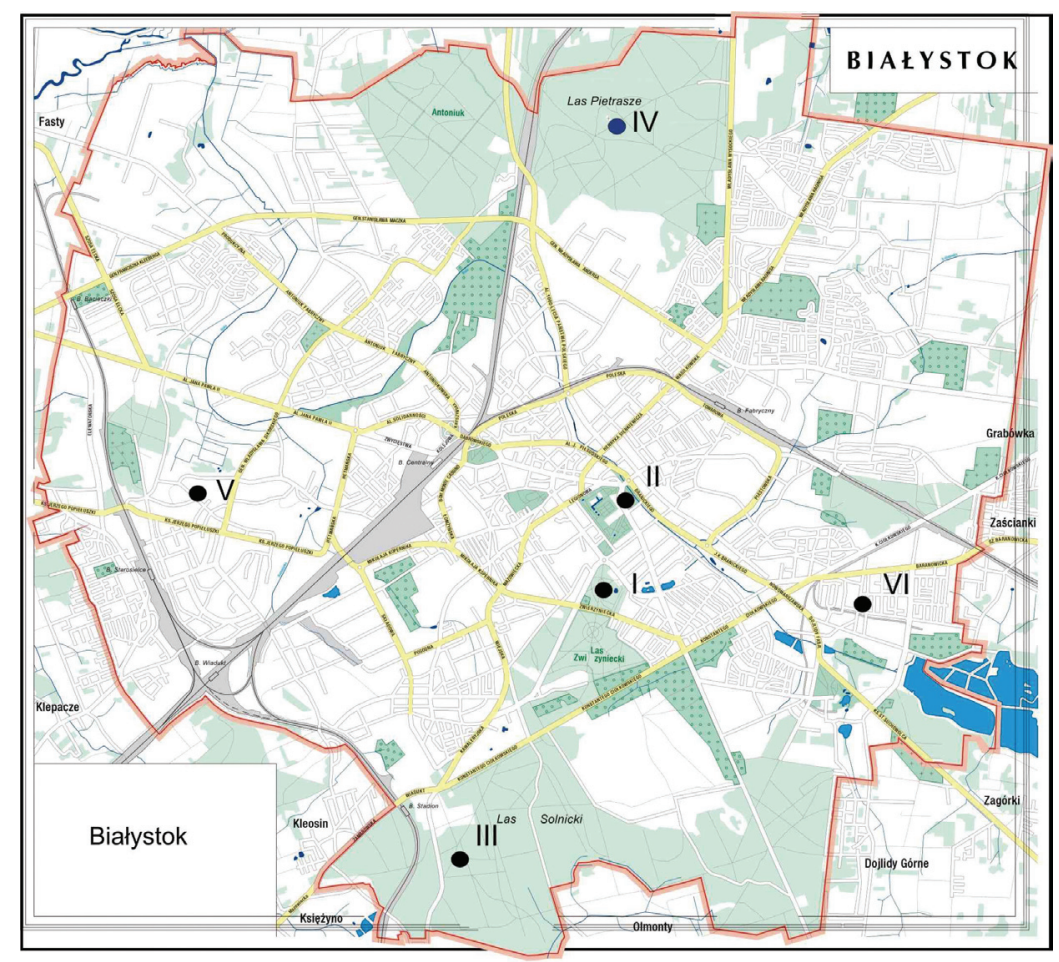


The species have been named according to Santesson et al. (2004), Melanelia sensu lato according to Blanco et al. (2004). Taxons of Lepraria and Cladonia coniocraea and C. fimbriata were performed using thin-layer chromatography TLC (Orange et al. 2001).

The concentration of trace elements were analyzed in the thalli of Hypogymnia physodes growing on the test sites. The thalli were collected in October 2009. The content of five elements was assessed: lead $(\mathrm{Pb})$, nickel $(\mathrm{Ni})$, copper $(\mathrm{Cu})$, zinc $(\mathrm{Zn})$ and iron $(\mathrm{Fe})$. Chemical analysis was performed according to the methodology developed for the determination of metals in plant material. One-gram samples of Hypogymnia physodes natural strains after drying at $105^{\circ} \mathrm{C}$ to evaporate water were wet mineralized in a mixture of $\mathrm{H}_{2} \mathrm{SO}_{4} / \mathrm{H}_{2} \mathrm{O}_{4}$, and the resulting solution was fed with a solution of $\mathrm{NH}_{3}$ to $\mathrm{pH} 3$, poured into flasks with a capacity of $100 \mathrm{~cm}^{3}$ and filled up to the mark with deionized water. Test mineralizates on the contents of lead, copper and zinc in the resulting solution were analyzed by anodic voltammetry inversion, using a trace analyzer of 746 VA. The concentration of nickel and iron were determined with the fiery technique of atomic absorption spectrometry using an atomic absorption spectrophotometer Unicam Solaar 929.

\section{Results and discussion}

For the observation points covered in the study a floral list of epiphytic species was drawn (Table 1) and there was noted the presence of natural strains of morphological forms that shape the sensitivity of these organisms as a response to the increased concentrations of anthropogenic substances in the atmosphere, mainly $\mathrm{SO}_{2}$ (Fig. 2).

The richest lichenobiota was registered on the bark of trees in the Planty Park (31 species) and the Solnicki Forest (26), while the poorest in Dojlidy estate (16). Epiphytic lichenbiota of the Solnicki Forest is also interesting (Table 1). Rare taxa were found here, such as Bryoria implexa and Usnea hirta on the bark of Betula pendula, Evernia prunastri, Pleurosticta acetabulum and Ramalina farinacea on the bark of Quercus robur, Chaenotheca furfuracea on the bark of Pinus sylvestris. In the Planty Park, which forms a kind of link between the Prince Józef Poniatowski Old Park and Zwierzyniecki Park, the bark of trees is colonized by rare species, like Evernia prunastri, Hypogymnia tubulosa, Parmelina tiliacea, Parmeliopsis ambigua, Physcia aipolia, Pseudevernia furfuracea, Tuckermanopsis chlorophylla.

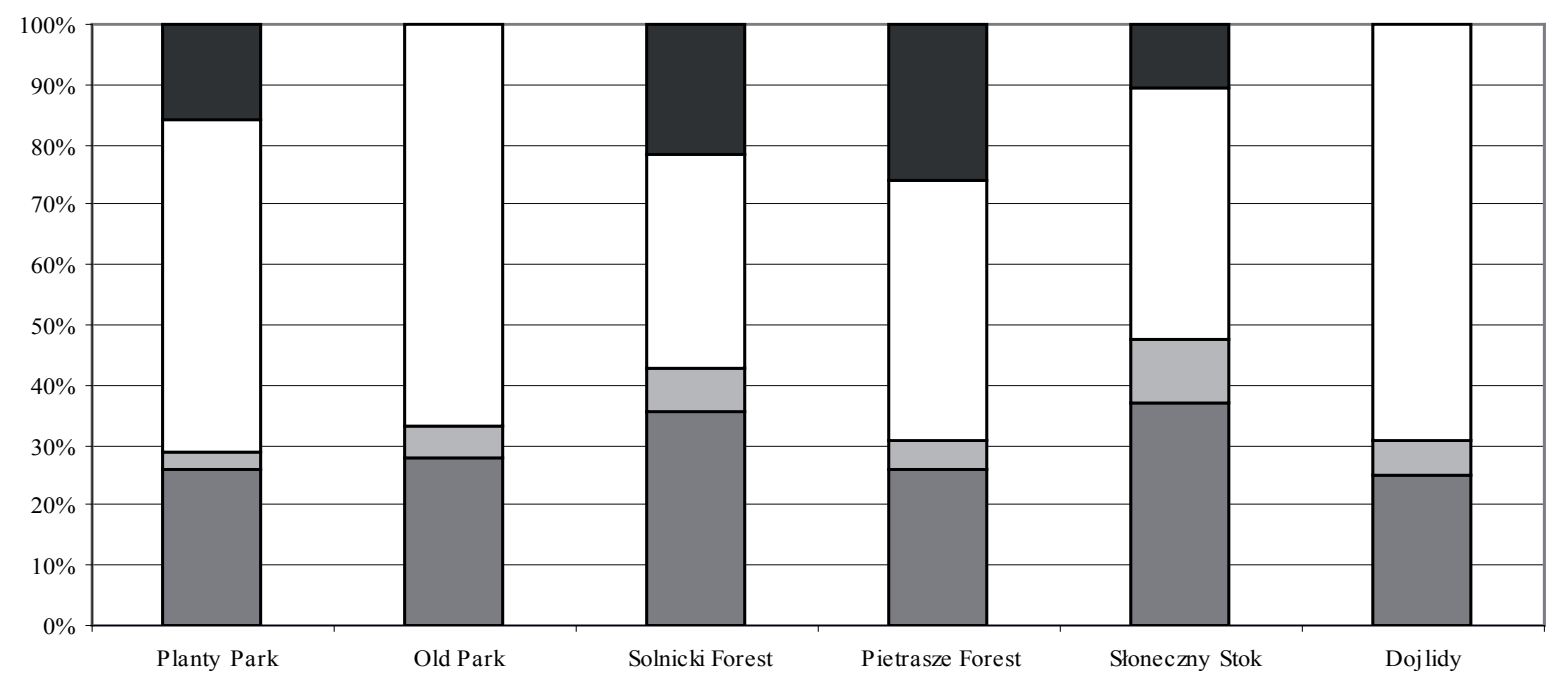

$\square$ crustose

$\square$ squamose

$\square$ foliose

fruticose

Figure 2. The percentage of morphological forms in the measurement points (stands) of Białystok in 2009 
Table 1. List of epiphytic lichen species at the six measurement points (stands) in Białystok in 2009

\begin{tabular}{|c|c|c|c|c|c|c|c|}
\hline \multirow{3}{*}{ Lp. } & \multirow{3}{*}{ Species } & \multicolumn{6}{|c|}{ Stand } \\
\hline & & 1 & 2 & 3 & 4 & 5 & 6 \\
\hline & & $\begin{array}{l}\text { Planty } \\
\text { Park }\end{array}$ & Old Park & $\begin{array}{l}\text { Solnicki } \\
\text { Forest }\end{array}$ & $\begin{array}{l}\text { Pietrasze } \\
\text { Forest }\end{array}$ & $\begin{array}{l}\text { Słoneczny } \\
\text { Stok }\end{array}$ & Dojlidy \\
\hline 1 & $\begin{array}{l}\text { Amandinea punctata (Hoffm.) Coppins } \\
\& \text { Scheid. }\end{array}$ & + & + & + & . & + & . \\
\hline 2 & $\begin{array}{l}\text { Bryoria implexa } \\
\text { (Hoffm.) Brodo \& D. Hawksw. }\end{array}$ & - & . & + & . & . & . \\
\hline 3 & $\begin{array}{l}\text { Caloplaca holocarpa (Hoffm. ex Ach.) } \\
\text { A.E. Wade }\end{array}$ & - & $\cdot$ & & . & . & + \\
\hline 4 & Candelaria concolor (Dicks.) Stein & . & . & + & . & + & . \\
\hline 5 & $\begin{array}{l}\text { Candelariella xanthostigma (Ach.) } \\
\text { Lettau }\end{array}$ & + & + & . & + & + & + \\
\hline 6 & Chaenotheca furfuracea (L.) Tibell & . & . & + & . & . & . \\
\hline 7 & $\begin{array}{l}\text { Cladonia coniocraea (Flörke) Spreng., } \\
\text { nom cons. }\end{array}$ & + & · & + & + & . & . \\
\hline 8 & Cladonia fimbriata (L.) Fr. & + & . & + & + & . & . \\
\hline 9 & Cladonia glauca Flörke & + & . & . & . & . & . \\
\hline 10 & Evernia prunastri (L.) Ach. & + & . & + & + & + & . \\
\hline 11 & $\begin{array}{l}\text { Hypocenomyce scalaris (Ach.) } \\
\text { M. Choisy }\end{array}$ & + & + & + & + & + & + \\
\hline 12 & Hypogymnia physodes (L.) Nyl. & + & + & + & + & + & + \\
\hline 13 & Hypogymnia tubulosa (Schaer.) Hav. & + & . & + & . & . & . \\
\hline 14 & Lecanora allophana Nyl. & . & . & . & + & . & . \\
\hline 15 & Lecanora carpinea (L.) Vain. & + & . & + & . & + & . \\
\hline 16 & Lecanora conizaeoides Nyl. ex Cromb. & + & + & . & + & + & + \\
\hline 17 & Lecanora populicola (DC.) Duby & . & . & + & . & . & . \\
\hline 18 & Lecanora pulicaris (Pers.) Ach. & + & . & + & . & + & . \\
\hline 19 & Lecanora saligna (Schrad.) Zahlbr. & . & . & + & . & . & . \\
\hline 20 & Lecanora symmicta (Ach.) Ach. & . & . & + & . & . & . \\
\hline 21 & $\begin{array}{l}\text { Lecidella elaeochroma (Ach.) } \\
\text { M. Choisy }\end{array}$ & . & . & + & . & . & . \\
\hline 22 & Lepraria incana (L.) Ach. & + & + & + & + & + & . \\
\hline 23 & $\begin{array}{l}\text { Melanohalea exasperatula (Nyl.) } \\
\text { O. Blanco et al. }\end{array}$ & + & + & . & . & . & + \\
\hline 24 & $\begin{array}{l}\text { Melanelixia fuliginosa (Fr. ex Duby) } \\
\text { O. Blanco et al. }\end{array}$ & + & + & . & . & · & + \\
\hline 25 & Parmelia sulcata Taylor & + & + & + & + & + & + \\
\hline 26 & Parmelina tiliacea (Hoffm.) Hale & + & . & . & . & . & . \\
\hline 27 & Parmeliopsis ambigua (Wulfen) Nyl. & + & . & . & + & . & . \\
\hline
\end{tabular}


Table 1. Cont.

\begin{tabular}{|c|c|c|c|c|c|c|c|}
\hline \multirow{3}{*}{ Lp. } & \multirow{3}{*}{ Species } & \multicolumn{6}{|c|}{ Stand } \\
\hline & & 1 & 2 & 3 & 4 & 5 & 6 \\
\hline & & $\begin{array}{l}\text { Planty } \\
\text { Park }\end{array}$ & Old Park & $\begin{array}{l}\text { Solnicki } \\
\text { Forest }\end{array}$ & $\begin{array}{l}\text { Pietrasze } \\
\text { Forest }\end{array}$ & $\begin{array}{l}\text { Słoneczny } \\
\text { Stok }\end{array}$ & Dojlidy \\
\hline 28 & $\begin{array}{l}\text { Phaeophyscia orbicularis (Neck.) } \\
\text { Moberg }\end{array}$ & + & + & . & + & + & + \\
\hline 29 & Phlyctis argena (Speng.) Flot. & + & . & . & . & . & . \\
\hline 30 & $\begin{array}{l}\text { Physcia adscendens H. Olivier nom. } \\
\text { cons. }\end{array}$ & + & + & . & . & + & + \\
\hline 31 & Physcia aipolia (Ehrh. ex Humb.) Fürnr. & + & . & . & . & . & . \\
\hline 32 & Physcia dubia (Hoffm.) Lettau & + & + & . & + & + & + \\
\hline 33 & Physcia stellaris (L.) Nyl. & + & + & + & + & + & + \\
\hline 34 & Physcia tenella (Scop.) DC. & + & + & + & . & . & . \\
\hline 35 & Physconia enteroxantha (Nyl.) Poelt & + & + & . & + & . & + \\
\hline 36 & $\begin{array}{l}\text { Pleurosticta acetabulum (Neck.) Elix \& } \\
\text { Lumbsch }\end{array}$ & . & . & + & . & . & . \\
\hline 37 & Pseudevernia furfuracea (L.) Zopf & + & . & & + & . & . \\
\hline 38 & Ramalina farinacea (L.) Ach. & . & . & + & . & . & . \\
\hline 39 & Ramalina fraxinea (L.) Ach. & . & . & & . & + & \\
\hline 40 & $\begin{array}{l}\text { Scoliciosporum chlorococcum (Graeve } \\
\text { ex Stenh.) Vězda }\end{array}$ & + & + & + & + & + & + \\
\hline 41 & $\begin{array}{l}\text { Tuckermanopsis chlorophylla (Willd.) } \\
\text { Hale }\end{array}$ & + & . & . & . & . & . \\
\hline 42 & Usnea hirta (L.) Weber ex F. H. Wigg. & . & . & + & + & . & . \\
\hline 43 & Xanthoria parietina (L.) Th. Fr. & + & + & + & . & + & + \\
\hline 44 & $\begin{array}{l}\text { Xanthoria polycarpa (Hoffm.) Th. Fr. } \\
\text { ex Rieber }\end{array}$ & + & + & + & + & + & + \\
\hline & Total: & 31 & 18 & 26 & 19 & 19 & 16 \\
\hline
\end{tabular}

Based on the evaluation of lichen species three composition zones with different degrees of pollution were distinguished:

Zone III (stand 2 - Prince Józef Poniatowski Old Park) the inner stunted growth zone, whose indicator species are: Phaeophyscia orbicularis, Physcia dubia, P. adscendens, Xanthoria parietina and X. polycarpa, Hypogymnia physodes (single thallus), Parmelia sulcata (single thallus) and Hypocenomyce scalaris, Lecanora conizaeoides, Lepraria incana, Scoliciosporum chlorococcum.

Zone IV (stand 4 - Dojlidy housing estate) - the central stunted growth zone, this zone is characterized by: Hypo- gymnia physodes, Parmelia sulcata, Melanelixia fuliginosa, Melanohalea exasperatula, Physconia enteroxantha, Candelariella xanthostigma, Lecanora carpinea, L. pulicaris.

Zone V (stands: 1 - Planty Park, 3 - Solnicki Forest, 4 - Pietrasze Forest, 5 - Sunny Slope housing estate) - the outer stunted growth zone, which is characterized by the occurrence of fruticose lichens less susceptible to contamination, namely: Bryoria sp., Evernia prunastri, Pseudevernia furfuracea, Usnea hirta, Ramalina sp.

The response of lichens to pollution depends, among others, on the morphology of thallus, because gas exchange takes place on the entire surface of the thallus, and there- 
fore the highest sensitivity to contamination is exhibited by the species with the most powerful thallus and those protruding from the ground. The degree of sensitivity of morphological forms is as follows, starting with the most vulnerable: fruticose, foliose, squamose and crustose (Fałtynowicz 1995).

The predominant form, occurring in three test points, two located in the city center ( 1 and 2 ), and one on the outskirts of the industrial district Dojlidy (4) was foliose thallus (Fig. 2). The second most numerous group were lichens representing crustose forms, characterized by a smooth, powdery structure, distinguished by ground attachment with their entire lower surface. The fruticose thallus was recorded in the urban forests, the Planty Park and the Sunny Slope estate situated on the outskirts. Squamose lichens represented mainly by species Hypocenomyce scalaris were found at all points of research.

In the research section 2 (Prince Józef Poniatowski Old Park), located in the city center, there was no occurrence of fruticose forms of lichens, which indicates heavily polluted air. In this stand foliose lichens are with small thalli, often poorly developed. Tree trunks are covered mostly with species with crustose and squamose thalli. In the test point I, located in the Planty Park the bark of trees is populated by single lichens with fruticose thalli (Evernia prunastri, Pseudevernia furfuracea).

In urban forests, the Solnicki Forest (3) and the Pietrasze Forest (4), located on the outskirts of the city, on the bark of trees there are well developed foliose thalli without any signs of necrosis, characterized by a greater sensitivity to the negative impact of $\mathrm{SO}_{2}$ and the incidence of this type of thallus reflects the air quality improvement in relation to the previous zones characterised by crustose and squamose thalli. In the Solnicki Forest a significant share of lichens, most sensitive to air pollution - fruticose lichens, were observed (including Bryoria implexa, Evernia prunastri, Ramalina farinacea, Usnea hirta).
On the bark of trees growing in residential areas (research points 5 and 6 ) a significant share of foliose lichens was registered. A poorer lichenbiota was observed on Dojlidy estate, which includes Białystok Meat Processing Plant, Dojlidy Brewery and Cold Store Białystok.

The results of the relationship between the degree of air pollution and the occurrence (abundance) of individual forms of epiphytic lichen morphology allows for the development of a lichen scale. The study area can be divided into three zones of air pollution:

Zone III (stand 2 - Prince Józef Poniatowski Old Park) - the inner stunted growth zone of heavily polluted air, in which besides crustose lichens, there are also squamose and small foliose lichens. $\mathrm{SO}_{2}$ concentration ranges from $100-150 \mathrm{mg} / \mathrm{m}^{3}$.

Zone IV (stand 6 - Dojlidy estate) - the central stunted growth zone with a concentration of $\mathrm{SO}_{2}$ within 70-100 $\mathrm{mg} / \mathrm{m}^{3}$, in which besides crustose and squamose lichens, there are also foliose lichens.

Zone V (stands: 1 - Planty Park, 3 - Solnicki Forest, 4 - Pietrasze Forest, 5 - Sunny Slope estate) - the outer stunted growth zone, with a concentration of $\mathrm{SO}_{2}$ within the limits from 50 to $70 \mathrm{mg} / \mathrm{m}^{3}$, in which besides crustose and foliose lichens, there are fruticose lichens.

Lichens observed during the study covered tree trunks at various heights, the thallus most resistant to pollution, a crustose form, occurred over the entire height of the tree trunks whereas foliose and squamose forms were characterized by a much lower altitude range.

After analyzing the contribution of morphological forms on research stands an attempt was made to analyze the chemical composition of trace elements in the thallus of Hypogymnia physodes. The study comprised five elements $(\mathrm{Cu}, \mathrm{Fe}, \mathrm{Ni}, \mathrm{Pb}, \mathrm{Zn})$ accumulated in the test lichen thallus. Their concentration in the thallus of Hypogymnia physodes was varied on the studied site (Table 2).

Table 2. Concentrations of heavy metals in thallus Hypogymnia physodes in the six measurement points (stands) of Białystok in 2009

\begin{tabular}{|l|l|c|c|c|c|c|}
\hline \multirow{2}{*}{$\begin{array}{l}\text { Number } \\
\text { of stand }\end{array}$} & \multirow{2}{*}{ Localization } & \multicolumn{5}{|c|}{ Average concentrations of heavy metals $[\mu \mathrm{g} / \mathrm{g}]$} \\
\cline { 3 - 7 } & & $\mathrm{Cu}$ & $\mathrm{Ni}$ & $\mathrm{Fe}$ & $\mathrm{Pb}$ & $\mathrm{Zn}$ \\
\hline 1 & Planty Park & 4.2 & 2.3 & 598.4 & 31.25 & 76.23 \\
\hline 2 & Old Park & 4.9 & 2.6 & 560.1 & 30.21 & 66.21 \\
\hline 3 & Solnicki Forest & 4.1 & 2.2 & 524.1 & 19.24 & 64.25 \\
\hline 4 & Pietrasze Forest & 5.2 & 3.1 & 591.5 & 21.54 & 79.24 \\
\hline 5 & Słoneczny Stok & 5.5 & 3.4 & 590.4 & 25.44 & 82.36 \\
\hline 6 & Dojlidy & 5.8 & 4.2 & 550.1 & 19.54 & 75.25 \\
\hline
\end{tabular}




\section{- Copper $(\mathrm{Cu})$}

The lowest concentration of copper in Hypogymnia physodes was found in the test points located in green areas - Forests: Solnicki and Pietrasze and Parks: Planty Park and Old Park (Table 2). Definitely the strongest air pollution was recorded in the copper in the district of Dojlidy. It is difficult to definitely identify the source of the pollution in the city - most likely these are industrial plants.

- Nickel (Ni)

The concentration of nickel in Hypogymnia physodes was in the range of 2.2 to $4.2 \mu \mathrm{g} / \mathrm{g}$. The highest concentrations were found in the outlying districts of the city Dojlidy and Sunny Slope, and the lowest in the samples from the Solnicki Forest and Planty Park.

\section{- Iron $(\mathrm{Fe})$}

The concentrations of iron in Hypogymnia physodes ranged from 524.1 to $598.4 \mu \mathrm{g} / \mathrm{g}$. The lowest concentration of iron was found in the thalli from the Solnicki Forest, and the highest in the city center.

- Lead $(\mathrm{Pb})$

Lead concentrations in Hypogymnia physodes ranged from 19.24 to $31.25 \mu \mathrm{g} / \mathrm{g}$. The areas with high accumulation of lead in thallus were the district center, where two parks are located: Old Park and Planty Park. These areas are the ones with the largest traffic volume taking place within the city of Białystok. The location of areas with varying lead content in lichen thallus in the rest of the city indicates the important role of emissions from mobile sources. The lowest level of lead contamination was found in the forest comlexes of the Pietrasze Forest and Solnicki Forest.

$$
\text { - Zinc (Zn) }
$$

In Białystok zinc concentrations in Hypogymnia physodes ranged from 64.25 to $82.36 \mu \mathrm{g} / \mathrm{g}$. The highest concentration of this metal was observed in the residential area in the Sunny Slope and Pietrasze Forest. Other islands with slightly lower air contamination with that metal are the Planty Park and Dojlidy.

The highest concentrations of $\mathrm{Cu}$ and $\mathrm{Ni}$ were found in one district - Dojlidy, where Meat Processing Plant (PMB), Cold Store Białystok and Dojlidy Brewery are located. The largest pollution in terms of area and value of $\mathrm{Pb}$ is located near the city center.

Although the emissions of various metals such as $\mathrm{Pb}$ and $\mathrm{Fe}$ have a different origin than the emissions of $\mathrm{Zn}, \mathrm{Cu}$ and $\mathrm{Ni}$, research has shown that areas with the highest and lowest concentrations of these metals coincide. It is related to the fact that clusters of the largest industrial plants in Białystok with the highest air emissions are in the peripheral areas of the city, and the main traffic communication in the city is in the center and on the major hubs connecting the center with the outlying districts of the city.

The occurrence of westerly winds in the area of the city of Białystok (SW, W, NW) results in a more frequent exposure of western lichens than the eastern ones, which is caused by a shift of the contaminated zone to the east.

The main toxic compound contained in the air in the largest quantities is sulfur dioxide and it is largely responsible for the death of natural strains of lichen thalli. Joint effects of toxic substances is greater than the sum of individual impacts. In the close proximity to transportation routes and in the most industrialized parts of the city with the main sources of air pollution, lichen biota is poorer because the fallout of toxic compounds is large and limits the growth of lichens.

As the distance from the emission source reduces the toxic effect of pollutants decreases due to the fall in the concentration of pollutants as well as to the presence of high greenery.

The monitoring studies carried out in Białystok indicated that the relative lichen desert zone does not grow through measures aimed at reducing emissions of harmful substances, including sulfur dioxide, for example, by replacing coal with more environmentally friendly fuels: natural gas, fuel oil. The concentration level of heavy metals in Hypogymnia physodes in ten years is maintained at a similar level (Matwiejuk 2007). The monitoring methods showed still existing varying air pollution in Białystok. In conclusion, the research points located on the green areas of the city are much less contaminated with heavy metals and $\mathrm{SO}_{2}$ than the points located in the center and the periphery.

Comparing the results obtained with the use of different lichen-indicative methods: floral, morphological forms participation and chemical analysis (analysis of heavy metal accumulation by the thallus of Hypogymnia physodes), their strong similarities should be emphasised.

Following this study of floristic research at the six points of Białystok and the historical analysis (Matwiejuk 2007) it appears that the number of species and species composition at the points remain on the same level. Here grow mainly the species for which the changes in the environment create favourable conditions for development. These are mainly common and frequent lichens, for example, Amandinea punctata, Hypogymnia physodes, Parmelia sulcata, Phaeophyscia orbicularis, Physcia adscendens, P. dubia, P. tenella, P. stellaris, Xanthoria parietina, $X$. polycarpa. Among the species that were recorded today there are also susceptible, fruticose species (Bryoria implexa, Evernia prunastri, Ramalina farinacea, $R$. fraxinea, Usnea hirta) and foliose (Hypogymnia tubulosa, Parmelina tiliacea, Pleurosticta acetabulum, Tuckermannopsis chlorophylla).

In Białystok, as in other cities, it is clear zonal distribution of lichens, but it has no lichen desert zone. The zone with the highest air pollution levels, a lichen desert zone, in other cities occupy considerable areas. Lichen desert zone occurs, e.g. in Kraków (Kiszka 1977), Toruń 
(Wilkoń-Michalska et al. 1988), Gdańsk, Gdynia and Sopot (Fałtynowicz et al. 1991). It is directly linked with the location of industry and pattern of prevailing winds. Lichen desert zone does not occur in Przemyśl (Kiszka 1999).

The studies also indicate that the relative city desert zone does not grow through measures aimed at reducing emissions of harmful substances, including sulfur dioxide, for example, by replacing coal with more environmentally friendly fuels: natural gas, fuel oil. The concentration level of heavy metals in the thallus of Hypogymnia physodes in ten years is maintained at a similar level. Compared to earlier years there was now a bit higher concentrations of lead, copper and nickel, while the lower iron and zinc (Table 3).

The average concentrations of accumulated elements in thalli Hypogymnia physodes in Białystok are lower than those given in different parts of Poland (Fabiszewski et al. 1983; Puszkar 1997; Kiszka 1998; Świergosz et al. 1998). Among the Polish cities, which performed an assessment of air pollution using lichens are Poznań (Kepel 1999) and Kielce (Jóźwiak 2007). In relation to these cities in Białystok reported lower concentrations of copper and lead, and higher iron and zinc.

The concentration of many heavy metals in Białystok is similar to the concentration found in thalli lichens of Finland (Halonen et al. 1993; Garty et al. 1997).

The methods used showed the still existing varying air pollution in Białystok. In conclusion, it should be stated that the research points located on the green areas of the city are much less contaminated with heavy metals and $\mathrm{SO}_{2}$ than the points located in the center and the periphery. This indicates an important role played by a dense vegetation within forest stands in the neutralization of the negative environmental factors.

Table 3. Concentrations of heavy metals in thallus Hypogymnia physodes in several districts of Białystok in 2000 (Matwiejuk 2007) and in the measurement points (stands) in 2009

\begin{tabular}{|c|c|c|c|c|c|c|}
\hline \multirow{2}{*}{ District } & \multirow{2}{*}{$\begin{array}{l}\text { Street (Matwiejuk 2007) and stands } \\
\qquad(1,2,4,5,6) \text { in } 2009\end{array}$} & \multicolumn{5}{|c|}{ Average concentrations of heavy metals $[\mu \mathrm{g} / \mathrm{g}]$} \\
\hline & & $\mathrm{Cu}$ & $\mathrm{Fe}$ & $\mathrm{Ni}$ & $\mathrm{Pb}$ & $\mathrm{Zn}$ \\
\hline \multirow[t]{2}{*}{ Śródmieście } & $\begin{array}{l}\text { Józef Piłsudski street } \\
\text { Rynek Kościuszki street }\end{array}$ & $\begin{array}{l}5.91 \\
6.10\end{array}$ & $\begin{array}{l}570.3 \\
865.1\end{array}$ & $\begin{array}{l}2.95 \\
2.78\end{array}$ & $\begin{array}{l}29.32 \\
22.26\end{array}$ & $\begin{array}{l}66.19 \\
71.21\end{array}$ \\
\hline & Park Old (stand 2) & 4.9 & 560.1 & 2.6 & 30.21 & 66.21 \\
\hline \multirow[t]{2}{*}{ Mickiewicza } & $\begin{array}{l}\text { Adam Mickiewicz street } \\
\text { Artur Grottger street } \\
\text { Modrzewiowa street }\end{array}$ & $\begin{array}{l}4.92 \\
6.25 \\
4.32 \\
\end{array}$ & $\begin{array}{l}804.5 \\
521.2 \\
541.7\end{array}$ & $\begin{array}{l}2.43 \\
3.04 \\
2.22\end{array}$ & $\begin{array}{l}33.51 \\
20.00 \\
18.61\end{array}$ & $\begin{array}{r}149.10 \\
86.16 \\
65.58\end{array}$ \\
\hline & Park Planty (stand 1) & 4.2 & 598.4 & 2.3 & 31.25 & 76.23 \\
\hline \multirow[t]{2}{*}{$\begin{array}{l}\text { Dojlidy, } \\
\text { Przemysłowe }\end{array}$} & $\begin{array}{l}\text { Zagłoba street } \\
\text { Sowlańska street } \\
\text { Gródecka street } \\
\text { Zaścianki street }\end{array}$ & $\begin{array}{l}6.15 \\
6.70 \\
6.54 \\
4.32\end{array}$ & $\begin{array}{l}683.5 \\
536.7 \\
519.2 \\
505.1\end{array}$ & $\begin{array}{l}2.86 \\
5.74 \\
5.61 \\
2.30\end{array}$ & $\begin{array}{l}24.11 \\
17.93 \\
18.39 \\
18.62\end{array}$ & $\begin{array}{l}72.64 \\
82.77 \\
79.22 \\
65.83\end{array}$ \\
\hline & Dojlidy (stand 6) & 5.8 & 550.1 & 4.2 & 19.54 & 75.25 \\
\hline \multirow[t]{2}{*}{$\begin{array}{l}\text { Pietrasze, } \\
\text { Wysockiego-Zgoda, Wygoda }\end{array}$} & $\begin{array}{l}\text { Pietrasze street } \\
\text { Wasilkowska street } \\
\text { Szmaragdowa street } \\
\text { Władysław Wysocki street } \\
\text { Władysław Bogusławski street }\end{array}$ & $\begin{array}{l}4.29 \\
7.26 \\
5.09 \\
5.31 \\
6.44\end{array}$ & $\begin{array}{l}673.0 \\
580.0 \\
802.3 \\
618.8 \\
770.1\end{array}$ & $\begin{array}{l}2.31 \\
8.45 \\
2.95 \\
2.18 \\
3.58\end{array}$ & $\begin{array}{l}16.51 \\
22.83 \\
27.75 \\
18.23 \\
26.59\end{array}$ & $\begin{array}{l}81.38 \\
92.98 \\
85.23 \\
74.30 \\
80.19\end{array}$ \\
\hline & Pietrasze Forest (stand 4) & 5.2 & 591.5 & 3.1 & 21.54 & 79.24 \\
\hline \multirow[t]{2}{*}{$\begin{array}{l}\text { Słoneczny Stok, } \\
\text { Leśna Dolina, } \\
\text { Zielone Wzgórza }\end{array}$} & $\begin{array}{l}\text { Wincenty Witos street } \\
\text { gen. Władysław Sikorski street } \\
\text { Upalna street } \\
\text { Powstańców street } \\
\text { Różana street } \\
\text { Batalionów Chłopskich street }\end{array}$ & $\begin{array}{l}6.25 \\
7.48 \\
6.24 \\
4.42 \\
6.72 \\
6.51 \\
\end{array}$ & $\begin{array}{l}587.5 \\
466.2 \\
512.7 \\
638.5 \\
665.2 \\
675.7\end{array}$ & $\begin{array}{l}3.12 \\
3.08 \\
5.53 \\
2.54 \\
3.17 \\
2.71\end{array}$ & $\begin{array}{l}22.14 \\
25.17 \\
19.00 \\
23.08 \\
28.54 \\
24.54\end{array}$ & $\begin{array}{r}79.25 \\
67.09 \\
108.60 \\
75.13 \\
87.22 \\
87.42\end{array}$ \\
\hline & Słoneczny Stok (5) & 5.5 & 590.4 & 3.4 & 25.44 & 82.36 \\
\hline
\end{tabular}


The conducted lichen-indicative studies may constitute another valuable reference material. It would be advisable to start constant monitoring studies in Białystok using lichens every 5-10 years to track actual changes in the natural environment of the city.

\section{Conclusion}

During the studies mainly the occurrence of foliose lichen thalli was noted, which indicates the average air pollution with industrial dusts and gases, especially sulfur dioxide.

The main source of air pollution in Białystok is the road transport, which reveals its negative effects both in the center and on the outskirts of town.

From the research it can be conluded that at present, within the territory of Białystok, the relative lichen desert conitues to maintain only on individual stands, and forest areas are most valuable enclaves of lichen vegetation and these are the areas with the least possible contamination.

\section{Acknowledgements}

I wish to express my thanks to Reviewers for their precious remarks and advice.

\section{References}

Blanco O., Crespo A., Divakar P. K., Esslinger T. L., Hawksworth D. L. \& Lumbsch H. T., 2004, Melanelixia and Melanohalea, two new genera segregated from Melanelia (Parmeliaceae) based on molecular and morphological data, Cambridge University Press Copyright, Mycol. Res. 108 (8): 873-884.

Bok G. (ed.), 2010, Nadzwyczajne zagrożenia środowiska województwa białostockiego [Extraordinary threat to the environment of the Białystok region], Wojewódzki Inspektorat Ochrony Środowiska w Białymstoku, Biblioteka Monitoringu Środowiska, Białystok.

Bystrek J., 1997, Podstawy lichenologii [The basics lichenology], Wydawnictwo Uniwersytetu Marii CurieSkłodowskiej, Lublin.

Fabiszewski J., Brej T. \& Bielecki K., 1983, Fitoindykacja wpływu huty miedzi na środowisko biologiczne [Fitoindication impact copper smelter on the biological environment], Ossolineum, Prace Wrocławskiego Towarzystwa Naukowego, B 207: 1-110.

Fałtynowicz W., 1995, Wykorzystanie porostów do oceny zanieczyszczenia powietrza. Zasady, metody, klucze do oznaczania wybranych gatunków [The using lichens to assess air pollution. The principles, methods, keys for the determination of selected species], Wydawnictwo Fundacja Centrum Edukacji Ekologicznej Wsi, Krosno. Fałtynowicz W., Izydorek I. \& Budzbon E., 1991, The lichen flora as bioindicator of air pollution of Gdańsk, Sopot and Gdynia, Monogr. Bot. 73: 1-52.

Garty J., 2001, Biomonitoring atmospheric heavy metals with lichens: theory and application, Critical Reviews in Plant Sciences 20 (4): 309-371.

Garty J., Kauppi M. \& Kauppi A., 1997, The infuence of air pollution on the concentration of airborne elements and on the production of stress-ethylene in the lichen Usnea hirta (L.) Weber em. Mot. transplanted in urban sites in Oulu, N Finland, Arch. Environ. Contam. Toxicol. 32: 285-290.

Halonen P., Hyvärinen M. \& Kauppi M., 1993, Emission related and repeated monitoring of element concentrations in the epiphytic lichen Hypogymnia physodes in a coastal area, W Finlandia, Ann. Bot. Fennici 30: 251-261.

Hawksworth D. L. \& Rose F., 1970, Qualitative scale for estimating sulphur dioxide air pollution in England and Wales using epiphytic lichens, Nature 227: 145-148.

Hyvärinen M., Soppela K., Halonen P. \& Kauppi M., 1993, A review of fumigation experiments on lichens, Aquilo Ser. Bot. 32: 21-31.

Jachnik E., 2006, Glony - bioindykatory zanieczyszczenia ekosystemu wodnego [Algae - bioindicators of aquatic ecosystem pollution], Aura 12: 26-27.

Jóźwiak M., 2007, Kumulacja metali ciężkich i zmiany morfologiczne w plechach porostu Hypogymnia physodes (L.) Nyl. [Accumulation of heavy metals and morphological changes in lichen thalli of Hypogymnia physodes (L.) Nyl.], Kieleckie Towarzystwo Naukowe, Kielce, Monitoring Środowiska Przyrodniczego 8: 51-56. Kepel A., 1999, Porosty Poznania jako wskaźnik zanieczyszczenia atmosfery, Rozprawa doktorska (manuskrypt) [Lichens of Poznań as an indicator of atmospheric pollution, PhD Thesis (manuscript)], Uniwersytet Adama Mickiewicza w Poznaniu, Poznań.

Kiszka J., 1977, Wpływ emisji miejskich i przemysłowych na florę porostów (Lichenes) Krakowa i Puszczy Niepołomickiej [The effect of urban and industrial emissions on the flora of lichens (Lichenes) of Kraków and Niepołomnicka Forest], Wydawnictwo Naukowe WSP w Krakowie, Prace Monogr. 19: 5-137.

Kiszka J., 1990, Lichenoidykacja obszaru województwa krakowskiego [Lichenoidication the province of Kraków], Stud. Ośr. Dokument. Fizjogr. 18: 201-212.

Kiszka J., 1998, Lichen flora as indicative of the environmantal degradation in the Czarna Wisełka and Biała Wisełka catchments, [in:] S. Wróbel (ed.), Environmental degradation of the Czarna Wisełka and Biała Wisełka catchments, Western Carpathians, Studia Natura 44: 53-71. 
Kiszka J., 1999, Porosty (Lichenes) oraz warunki bioekologiczne Przemyśla [Lichens and bioecological conditions of Przemyśl], Arboretum Bolestraszyce 6: 1-86.

Kłos A., 2007, Porosty - biowskaźniki i biomonitory zanieczyszczenia środowiska [The lichens - biomarkers and biomonitores of environmental pollution], Chemia. Dydaktyka, Ekologia, Metrologia 12.1-2: 61-77.

Kondracki J., 2002, Geografia regionalna Polski [The regional geography of Poland], Państwowe Wydawnictwo Naukowe, Warszawa.

Kozik R., 1970, Porosty miasta Tarnowa i okolicy [The lichens of the city Tarnów and its surroundings], Fragmenta Floristica et Geobototanica, Supplement 6 (2): $361-381$.

Matwiejuk A., 2007, Porosty Białegostoku, jako wskaźniki zanieczyszczenia atmosfery [The lichens of Białystok as an indicators of atmospheric pollution], Wydawnictwo Ekonomia i Środowisko, Białystok.

Nash T. H. III, 1989, Metal tolerance in lichens, [in:] A. J. Shaw (ed.), Heavy Metal Tolerance in Plants: Evolutionary Aspects, CRC Press, Boca Raton: 119-131.

Nash T. H. III \& Gries C., 2002, Lichens as bioindicators of sulfur dioxide, Symbiosis 33 (1): 1-22.

Nash T. H. III \& Wirth V. (eds.), 1988, Lichens, bryophytes and air quality, Bibliotheca Lichenologica 30: 231-267.

Nimis P. L. \& Purvis O. W., 2002, Monitoring lichens as indicators of pollution, [in:] P. L. Nimis, C. Scheidegger, P. A. Wolseley (eds.), Monitoring with Lichens - Monitoring Lichens, NATO Science Series, IV Earth and Environmental Sciences 7: 7-10.

Nimis P. L., Scheidegger C. \& Wolseley P. A. (eds.), 2002, Monitoring with Lichens - Monitoring Lichens, NATO Science Series, IV Earth and Environmental Sciences 7: $1-403$.

Nylander W., 1866, Les lichens du Jordin du Luxembourg [The lichens of Jordin of Luxemburg], Bull. Soc. Bot. France 13: 364-372.

Orange A., James P. W. \& White F. J., 2001, Microchemical methods for the identification of lichens, British Lichen Society, London.

Puszkar L., 1997, Ocena lichenoindykacyjna zanieczyszczeń powietrza w rejonie Puław [Lichenoindication assessment of air pollution in the vicinity of Puławy], Insty- tut Uprawy Nawożenia i Gleboznawstwa, Puławy (rozprawa habilitacyjna), Dział Wydawnictw Naukowych, Puławy.

Richardson D. H. S., 1992, Pollution monitoring with lichens, Naturalists' Handbooks 19, Richmond Publishing Co., Ltd. Slough, England.

Rocznik Statystyczny Województwa Podlaskiego [Statistical Yearbook of Podlaskie Voivodship], 2009, Urząd Statystyczny w Białymstoku, Białystok.

Rydzak J., 1953, Rozmieszczenie i ekologia porostów miasta Lublina [Distribution and ecology of lichens from Lublin], Annales UMCS, Sec. C 8 (9): 233-356.

Santesson R., Moberg R., Nordin A., Tønsberg T. \& Vitikainen O., 2004, Lichen-forming and lichenicolous fungi of Fennoscandia, Museum of Evolution, Uppsala University.

Sauberer A., 1951, Die Verteilung rindenbewohnender Flechten in Wien ein bioklimatisches Grosstadtproblem [The distribution of lichens in Vienna, a big city problem bioclimatic], Wetter Leben 3: 116-121.

Sernander R., 1926, Stockholm's Nature, Almquist and Wiksells, Uppsala \& Stockholm.

Świergosz R., Sawicka-Kapusta K., Nyholm N. E. I., Zwolińska A. \& Orkisz A., 1998, Effects of environmental metal pollution on breeding populations of pied and collared flycatchers in Niepołomice Forest, Southern Poland, Environmental Pollution 102: 213-220.

Ustawa, 2001, Ustawa z dnia 27 kwietnia 2001 roku o prawie ochrony środowiska, Dz. U. Nr 62 (z dnia 20 czerwca 2001 r.), poz. 627 [Act of 2001, Act of 27 April 2001 of Environmental Protection. Journal of Laws no. 62 (of 20 June 2001), pos. 627].

Wilkoń-Michalska J., Głazik N. \& Kalińska A., 1988, Porosty miasta Torunia [The Lichens of Toruń town], Acta Univ. N. Copernici 63, Biologia 29: 209-253.

Vaarna V. V., 1934, Helsingin kaupungin puiden ja pensaiden jäkäläkasvisto [The Lichens of trees and shrubs of Helsinki town], Annales Bot. Soc. Zool.-Bot. Fenn. Vanamo 5 (6): 1-32.

Zimny H., 2006, Ekologiczna ocena stanu środowiska bioindykacja i biomonitoringu [Ecological assessment of the environment - biomonitoring and bioindication], Agencja reklamowo-wydawnicza Arkadiusz Grzegorczyk, Warszawa. 